\title{
Regulation of Rat Mesangial Cell Growth by Diadenosine Phosphates
}

\author{
Stefan Heidenreich, Martin Tepel, Hartmut Schlüter, Bärbel Harrach, and Walter Zidek \\ Med. Univ.-Poliklinik, Institut für Arterioskleroseforschung, University of Münster, Germany
}

\begin{abstract}
The newly recognized human endogenous vasoconstrictive dinucleotides, diadenosine pentaphosphate $\left(\mathbf{A P}_{5} \mathbf{A}\right)$ and diadenosine hexaphosphate ( $\left.A_{6} A\right)$, were tested for growth stimulatory effects in rat mesangial cells (MC). Both $\mathbf{A P}_{\mathbf{5}} \mathbf{A}$ and $\mathbf{A P}_{6} \mathbf{A}$ stimulated growth in micromolar concentrations. The growth stimulatory effect exceeded that of ATP, $\alpha, \beta$ methylene ATP, adenosine 5'-O-(3-thio)triphosphate and UTP. Both diadenosine phosphates potentiated the growth response to platelet-derived growth factor, but not to insulin-like growth factor-1. To further elucidate the site of action in the cell cycle, RNA and protein synthesis were assessed. $\mathbf{A P}_{5}$ and $\mathbf{A P}_{6} \mathrm{~A}$ stimulated protein synthesis, but not RNA formation. Furthermore, both agents increased cytosolic free $\mathrm{Ca}^{2+}$ concentration. It is concluded that $\mathbf{A P}_{5} \mathrm{~A}$ and $\mathbf{A P}_{6} \mathrm{~A}$ may play a regulatory role in $\mathrm{MC}$ growth as progression factors and possibly modify MC proliferation in glomerular disease. (J. Clin. Invest. 1995. 95:2862-2867.) Key words: mesangial cells - diadenosine phosphates PDGF • IGF-1 - cytosolic free $\mathrm{Ca}^{2+}$
\end{abstract}

\section{Introduction}

In inflammatory glomerular diseases and in glomerulosclerosis one of the central features is the proliferation of mesangial cells (MC). ${ }^{1}$ The mechanisms of MC proliferation are incompletely understood, but there is a growing body of information linking specific growth factors such as the platelet-derived growth factor (PDGF) or basic fibroblast growth factor to glomerular proliferative diseases (1-3). Glomerular MC can both produce and react to various polypeptide growth factors. Thereby MC activate inflammatory processes and promote $\mathrm{MC}$ proliferation, acting both in a paracrine and autocrine fashion $(4,5)$.

Recently, diadenosine pentaphosphate $\left(\mathrm{AP}_{5} \mathrm{~A}\right)$ and diadenosine hexaphosphate $\left(\mathrm{AP}_{6} \mathrm{~A}\right)$ have been described as novel endogenous vasopressor agents (6). Generally, diadenosine phosphates have been found in prokaryonts, in animals including mammalian organisms and in man (7). In mammals mainly the actions of diadenosine triphosphate and diadenosine tetra-

Address correspondence to Prof. W. Zidek, Med. Univ.-Poliklinik, Albert-Schweitzer-Str. 33, 48129 Münster, Germany. Phone: 251838019; FAX: 251-837545.

Received for publication 9 September 1994 and in revised form 12 January 1995

1. Abbreviations used in this paper: $\mathrm{CM}$, culture medium; MC, mesangial cells.

J. Clin. Invest.

(C) The American Society for Clinical Investigation, Inc.

0021-9738/95/06/2862/06 \$2.00

Volume 95, June 1995, 2862-2867 phosphate have been characterized. Both compounds are potent coronary and mesenterial vasodilators $(8,9)$. Furthermore, changes in the intracellular concentration of diadenosine tetraphosphate may be involved in cellular proliferation (10-12). As to the type of receptors, there are divergent findings in literature. Hilderman et al. identified a unique receptor for diadenosine phosphates $(13,14)$, but on the other hand a subtype of purinergic receptors, the $\mathrm{P} 2 \mathrm{x}$ receptor, may be activated by diadenosine phosphates $(15,16)$.

Since a number of vasopressor hormones, such as angiotensin II, vasopressin and endothelin, also act as growth factors on vascular smooth muscle cells or MC $(17,18)$, it was tested in the present study, whether also $\mathrm{AP}_{5} \mathrm{~A}$ and $\mathrm{AP}_{6} \mathrm{~A}$ stimulate growth of MC. Furthermore, both dinucleotides were tested for interactions with polypeptide growth factors.

\section{Methods}

Animals and culture of glomerular mesangial cells. 3-mo-old male Wistar-Kyoto rats (WKY) were fed a standard pellet diet and water ad libitum. According to previously described methods $(17,19-21)$ whole glomeruli were isolated by serial sieving of minced renal cortical tissue from blood-free rat kidneys. Intact glomeruli without tubular contamination were digested in collagenase (type CLS4, $184 \mathrm{U} / \mathrm{ml}$ ) under continuous gentle shaking at $37^{\circ} \mathrm{C}$ for $30 \mathrm{~min}$ according to a modified technique by Striker and Striker (21). This procedure results in digestion of the glomerular basement membrane and in shedding of epithelial cells (17). After repeated centrifugation and washing, primary cultures of glomerular MC were obtained from outgrowths of remnant glomeruli incubated in MC culture medium (CM) supplemented with $15 \%$ ( vol/vol) fetal calf serum (FCS; Boehringer Mannheim, Germany) at $37^{\circ} \mathrm{C}$ in a humidified atmosphere of $5 \% \mathrm{CO}_{2} / 95 \%$ air. The $\mathrm{MC}$ culture medium consisted of RPMI 1640 medium (Biochrom, Berlin, Germany), supplemented with $50 \mathrm{U} / \mathrm{ml}$ penicillin, $50 \mu \mathrm{g} / \mathrm{ml}$ streptomycin, $1 \mathrm{mM}$ L-glutamine (GIBCO, Eggenstein, Germany), $1 \mathrm{ml} / \mathrm{dl}$ non-essential amino acids, and heat-inactivated $\left(56^{\circ} \mathrm{C}, 30 \mathrm{~min}\right) \mathrm{FCS}$ as indicated. Until the third passage the MC culture medium also contained $5 \mu \mathrm{g} / \mathrm{ml}$ bovine insulin, $5 \mathrm{mg} / \mathrm{ml}$ transferrin, and $5 \mathrm{ng} / \mathrm{ml}$ sodium selenit (22). The medium was changed initially after $24 \mathrm{~h}$ and then every $2-3 \mathrm{~d}$. Homogenous MC outgrowths were observed after 5-7 d and reached confluency within 2-3 wk. Pure MC cultures were identified by stellate shaped cells growing in interwoven layers by morphological characterization and positive immunofluorescent staining for myosin, MHC I antigens and extracellular type IV collagen and fibronectin. Staining for myosin was performed with indirect immunofluorescence microscopy using rabbit immunoglobulin (IgG) directed to smooth muscle cell-specific myosin and fluorescein isothiocyanate-conjugated goat IgG to rabbit IgG. These studies showed uniformly strong positive staining of distinct longitudinal fibrils in all observed cells, which is a staining pattern considered to be indicative for MC (20). MC did not stain for rat common leucocyte antigen, cytokeratin, and factor VIII associated antigen, thus excluding the presence of epithelial cells or endothelial cells $(21,23)$. Confluent monolayers were passaged by washing $\mathrm{MC}$ with physiological salt solution (PSS, containing [in $\mathrm{mM}$ ] $\mathrm{NaCl} 135, \mathrm{KCl} \mathrm{5,} \mathrm{CaCl}_{2} 1$, $\mathrm{MgCl}_{2} 1$, glucose 5.5, and $N$-2-hydroxyethylpiperazine- $N^{\prime}$-2-ethanesulfonic acid [Hepes] 10, $\mathrm{pH} 7.4)$ with addition of trypsin $(0.125 \% \mathrm{wt} /$ vol ) and ethylene diamine tetraacetic acic $(0.01 \% \mathrm{wt} / \mathrm{vol})$ for $5 \mathrm{~min}$ at $37^{\circ} \mathrm{C}$ under gentle agitation before $\mathrm{MC}$ culture medium containing 
$10 \%$ FCS was filled up. The concentration of FCS was reduced to $10 \%$ after the second passage and experiments were carried out using MC between the fourth and sixth passage. Cells were free of mycoplasma as determined by repeated staining with $4^{\prime} 6^{\prime}$-diamidine-2' -phenylindole dihydrochloride (Boehringer Mannheim). Prior to each experiment, the medium was changed from $10 \%$ to $0.5 \%$ FCS for $3 \mathrm{~d}$ to induce cellular quiescence, leaving the $M C$ in a resting state, the $G_{0} / G_{1}$ phase (24).

Cell proliferation assays. MC were subcultured in 96-well dishes (Falcon Labware, Cockeysville, MD) at a density of $5 \times 10^{4}$ cells $/ \mathrm{ml}$ and kept in CM with $2.5 \%$ FCS for $24 \mathrm{~h}$ to reach a subconfluent monolayer. After that, the cells were growth arrested for $72 \mathrm{~h}$ with RPMI 1640 plus $0.5 \%$ fetal calf serum without affecting cell adherence to culture wells or viability as checked by trypan blue vital dye exclusion. Quiescent MC were then exposed to fresh CM with $0.5 \%$ FCS with and without the tested agonists for another $48 \mathrm{~h}$ incubation period. For the last $6 \mathrm{~h} \mathrm{MC}$ were pulsed with $2 \mu \mathrm{Ci} / \mathrm{ml}\left[{ }^{3} \mathrm{H}\right]$ thymidine (specific activity $5.0 \mathrm{Ci} / \mathrm{mmol}$ ), washed extensively with medium, trypsinized, and harvested onto filter paper by an automated cell harvester. Incorporated counts were measured by a liquid scintillation counter. Additional experiments for estimation of cell growth were performed by counting MC numbers microscopically and by measuring $\left[{ }^{3} \mathrm{H}\right]$ thymidine incorporation into acid-precipitable material. For these experiments, MC were seeded out in 24-well culture dishes at a density of $5 \times 10^{4}$ cells $/ \mathrm{ml}$ and incubated for identical periods as described above. After the last 6 h of $\left[{ }^{3} \mathrm{H}\right]$ thymidine pulse $(2 \mu \mathrm{Ci} / \mathrm{ml})$, the cells were washed with phosphate-buffered saline containing an excess of unlabeled thymidine and solubilized in $1 \mathrm{ml} 0.1 \%$ sodium dodecyl sulfate (SDS) before bovine serum albumin (BSA; $10 \mu \mathrm{l}, 10 \%$ ) was added as a carrier protein. Precipitation on ice was performed with $200 \mu 120 \%$ trichloroacetic acid (TCA) overnight. TCA-precipitable material was pelleted by centrifugation at $2,000 \mathrm{~g}$, dissolved in $0.5 \mathrm{M} \mathrm{NaOH}$, and transferred for liquid scintillation counting. All experiments gave results comparable to the aforementioned method.

Determination of cell cycle. The cell cycle of MC was determined by flow-cytometric analysis. Monolayer cultures were trypsinized, centrifuged at $400 \mathrm{~g}$ for $5 \mathrm{~min}$ at $4^{\circ} \mathrm{C}$, and the pellet was washed in culture medium without FCS. Further disaggregation with trypsin, enzymatic digestion of RNA, and staining of isolated nuclei with propidium iodide were carried out using a set of reagents (Cycle Test Plus DNA Reagent Kit; Becton Dickinson, Erembodegem, Belgium) according to the instructions of the manufacturer. DNA content was measured using a FACScan flow cytometer (Becton Dickinson). The percentage of cells in each phase of the cell cycle was estimated with an analysis model calculating the $\mathrm{S}$ phase from a rectangle (RFIT model).

Determination of RNA and protein synthesis. Subconfluent MC (5 $\times 10^{4}$ cells $/ \mathrm{ml}$ ) were growth arrested in 24-well dishes by culturing them for $72 \mathrm{~h}$ in CM with $0.5 \%$ FCS. Thereafter, culture supernatants were exchanged by fresh CM with $0.5 \%$ FCS with and without agonists for a further $6-48 \mathrm{~h}$ culture period. The MC were pulsed during the last $6 \mathrm{~h}$ with $2 \mu \mathrm{Ci} / \mathrm{ml}\left[{ }^{3} \mathrm{H}\right.$ ] uridine (specific activity $27 \mathrm{Ci} / \mathrm{mmol}$ ) for determination of RNA synthesis or $2 \mu \mathrm{Ci} / \mathrm{ml} \mathrm{[}{ }^{3} \mathrm{H}$ ] leucine (specific activity $42 \mathrm{Ci} / \mathrm{mmol}$ ) for quantitation of protein synthesis, as described earlier (25). After pulsing, the cells were extensively washed with warm phosphate-buffered saline, lysed in $1 \mathrm{ml}$ SDS $(0.1 \%)$, and transferred after supplementation of $10 \mu \mathrm{l} 10 \%$ BSA into an Eppendorf tube for TCA precipitation ( $200 \mu \mathrm{l}, 20 \%$ ) overnight on ice. The acid-precipitable material was washed by centrifugation, dissolved in $0.5 \mathrm{M} \mathrm{NaOH}$, and counted using a liquid scintillation counter.

Measurements of cytosolic free calcium concentration $\left(\left[\mathrm{Ca}^{2+}\right]_{i}\right)$. $\left[\mathrm{Ca}^{2+}\right]_{\mathrm{i}}$ in $\mathrm{MC}$ was measured using the calcium-sensitive fluorescent dye fura 2 according to previously described methods $(22,26,27)$ using a Spectrofluorophotometer RF-5001 PC (Shimadzu, Tokyo, Japan) with intracellular calcium measurement software (Shimadzu). Light source was a $150 \mathrm{~W}$ xenon lamp with ozone self-dissociation function. At the end of each measurement $1 \mathrm{mM}$ digitonin, then $5 \mathrm{mM}$ ethyleneglycolbis-(aminoethylether)-tetraacetic acid (EGTA) were sequentially added to determine the maximum ( $R \max$ ) and the minimum ( $R \min$ ) of the $340 / 380 \mathrm{~nm}$ excitation fluorescence ratio. Control experiments con- firmed that further increase of digitonin or EGTA concentration had no effect on Rmax or Rmin, respectively. $\left[\mathrm{Ca}^{2+}\right]_{i}$ was calculated according to the equation reported by Grynkiewicz et al. (28). Cytosolic fura2 concentration was estimated to be $<100 \mu \mathrm{M}$ by comparing the fluorescence of a standard solution of fura 2 free acid in the presence of unloaded cells. The autofluorescence of the agonists used was negligible.

Purification of the diadenosine phosphates $A P_{5} A$ and $A P_{6} A . \mathrm{AP}_{5} \mathrm{~A}$ and $A P_{6} A$ were used after purification of the preparations obtained from Sigma. The HPLC equipment consisted of a L-6200 gradient pump (Merck, Darmstadt, Germany), coupled to a Rheodyne injector (Latek, Heidelberg, Germany) an UV-HPLC detector (Lambda-Max 481; Waters), a two-channel compensation recorder (Pharmacia Biosystems, Freiburg, Germany) and a RediFrac fraction collector (Pharmacia Biosystems, Freiburg, Germany). A Mono Q HR 5/5 ( $\mathrm{Cl}^{-}$-form) anionexchange column from Pharmacia (Freiburg, Germany) and a Lichrospher RP select B reversed phase column $(4 \times 250 \mathrm{~mm})$ from Merck (Darmstadt, Germany) were used. HPLC-grade water and HPLC-grade acetonitrile were from Baker (Groß-Gerau, Germany). All other chemicals were from Sigma.

$10 \mathrm{mg}$ of $\mathrm{AP}_{5} \mathrm{~A}$ resp. $\mathrm{AP}_{6} \mathrm{~A}$, dissolved in $1 \mathrm{ml}$ of eluent $\mathrm{A}$, were purified with an anion-exchange column. Eluent $A$ was made up of 10 $\mathrm{mM} \mathrm{K}_{2} \mathrm{HPO}_{4}\left(\mathrm{pH} 8\right.$ ) in water and eluent $\mathrm{B}$ of $10 \mathrm{mM} \mathrm{K}_{2} \mathrm{HPO}_{4}(\mathrm{pH} 8$ ) with $1 \mathrm{M} \mathrm{NaCl}$. The following gradient was run: 0-11 min: $100 \% \mathrm{~A}$, 11-21 min: 0-15\% B, 21-71 min: 15-40\% B. The main UV-absorbing peak (measured at $254 \mathrm{~nm}$ ) was collected and concentrated to dryness in a Speed-Vac concentrator.

Next the sample was dissolved in $1 \mathrm{ml}$ eluent C ( $40 \mathrm{mM}$ triethylammonium acetate in water) and chromatographed on a reversed phase column. Elution was performed from 0 to $20 \mathrm{~min}$ with $100 \%$ eluent $\mathrm{C}$, with a linear gradient in $4 \mathrm{~min}$ from 0 to $2 \%$ eluent $\mathrm{D}$ ( $80 \%$ acetonitrile), in $46 \mathrm{~min}$ from 2 to $7 \%$ eluent $\mathrm{D}$, in $6 \mathrm{~min}$ from 7 to $60 \%$ eluent $\mathrm{D}$ and in $1 \mathrm{~min}$ from 60 to $100 \%$ eluent $\mathrm{D}$ with a flow-rate of $0.5 \mathrm{ml} / \mathrm{min}$. The main UV-absorbing peak was collected and the amount of the purified dinucleotide was calculated after UV-spectroscopic measurement of the absorbance of the sample. The fraction was divided into fractions containing $1 \mathrm{mg}$ of the dinucleotide and then concentrated to dryness in a Speed-Vac concentrator. The purified samples were analyzed using matrix-assisted laser desorption/ionisation mass spectrometry (MALDI-MS) as described below. After purification, MALDI-MS revealed a single mass peak of 917 and $997 \mathrm{D}$, which could be attributed to $\mathrm{AP}_{5} \mathrm{~A}$ or $\mathrm{AP}_{6} \mathrm{~A}$, respectively.

Matrix-assisted laser desorption/ionisation mass spectrometry (MALDI MS). MALDI MS was performed as described earlier (6, 29). A reflector-type time-of-flight mass spectrometer, equipped with a nitrogen laser ( $337 \mathrm{~nm}$, pulselength $4 \mathrm{ns)}$ ) was used for ion generation and mass analysis.

Reagents. Recombinant human PDGF B/B and IGF-1 expressed by E. coli were obtained from Boehringer Mannheim (Germany). Antisera for immunohistochemistry were purchased from Dako (Hamburg, Germany), ICN (Eschwege, Germany) and Sigma. Polyclonal rabbit antibody to PDGF B/B was from Genzyme (lot No. 84654; Cambridge, MA) and administered in an amount of $5 \mu \mathrm{g} / \mathrm{ng}$ PDGF. Tritium-labeled thymidine, uridine, and leucine were from Amersham Buchler (Braunschweig, Germany), fura-2 acetoxymethylester from Calbiochem (La Jolla, CA). $\alpha, \beta$ methylene adenosine triphosphate ( $\alpha, \beta$ methylene ATP), ATP and uridine triphosphate (UTP) were from Sigma, adenosine 5'-O-(3-thio) triphosphate (ATP $\gamma \mathrm{S}$ ) from Boehringer Mannheim.

Statistical analysis. Data are presented as mean \pm SD. Where error bars do not appear on figures, errors are within the symbol size. Original tracings shown were computed by locally weighted scatterplot smoothing (GraphPad Software Inc., San Diego, CA). Results were tested for statistical significance using analysis of variance (computer software SPSS for windows, Chicago, IL).

\section{Results}

Effects of $A P_{5} A$ and $A P_{6} A$ on $M C$ proliferation. $\mathrm{AP}_{5} \mathrm{~A}$ and $\mathrm{AP}_{6} \mathrm{~A}$ induced a dose-dependent increase in DNA synthesis in 


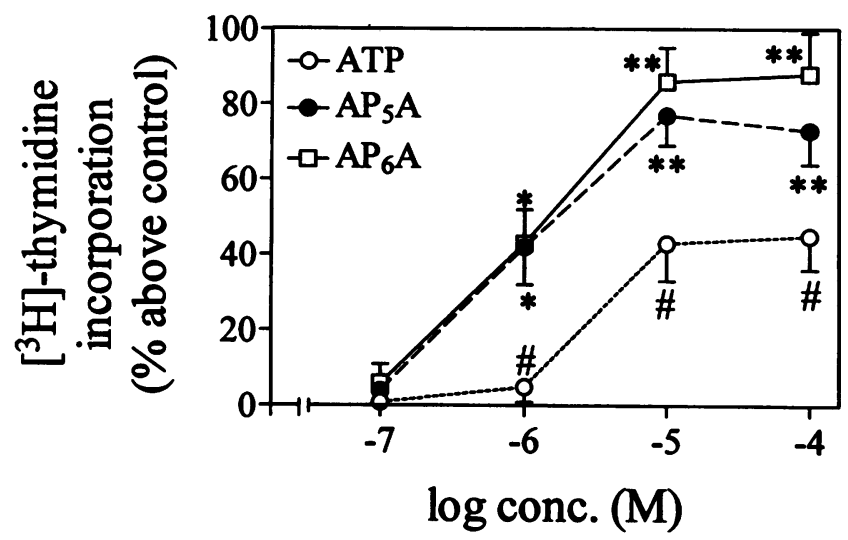

Figure 1. $\left[{ }^{3} \mathrm{H}\right]$ Thymidine incorporation (in \% above control) of mesangial cells stimulated by adenosine triphosphate (ATP), diadenosine pentaphosphate $\left(\mathrm{AP}_{5} \mathrm{~A}\right)$, and diadenosine hexaphosphate $\left(\mathrm{AP}_{6} \mathrm{~A}\right) . \mathrm{Ab}-$ scissa: $\log$ of concentrations in $\mathrm{M}$. Data are means \pm SD from five independent experiments with 10 cultures each. $* P<0.05 ; * * P<0.01$, each compared to control; " $P<0.05$ compared with $\mathrm{AP}_{5} \mathrm{~A}$ and $\mathrm{AP}_{6} \mathrm{~A}$.

quiescent $\mathrm{MC}$ as determined by $\left[{ }^{3} \mathrm{H}\right]$ thymidine uptake (Fig. 1). The maximum effect was obtained at diadenosine phosphate concentrations of $10^{-5} \mathrm{M}$, which induced an increase of MC proliferation $77 \pm 8 \%$ above control for $\mathrm{AP}_{5} \mathrm{~A}$ and of $86 \pm 9 \%$ above control for $\mathrm{AP}_{6} \mathrm{~A}$ (both $P<0.01$ ). Growth responses to $\mathrm{AP}_{5} \mathrm{~A}$ and $\mathrm{AP}_{6} \mathrm{~A}$ were similar. Compared with $\mathrm{ATP}$, which is a well characterized mitogenic cofactor for $\mathrm{MC}, \mathrm{AP}_{5} \mathrm{~A}$ and $\mathrm{AP}_{6} \mathrm{~A}$ induced a significantly elevated $\mathrm{MC}$ proliferation at concentrations between $10^{-6}$ and $10^{-4} \mathrm{M}$ (both $P<0.05$ ). Counting $\mathrm{MC}$ after application of $\mathrm{AP}_{5} \mathrm{~A}$ and $\mathrm{AP}_{6} \mathrm{~A}$ microscopically (Table I) gave similar results for MC proliferation as $\left[{ }^{3} \mathrm{H}\right]$ thymidine incorporation studies, so that $\mathrm{MC}$ growth responses to agonists were documented by $\left[{ }^{3} \mathrm{H}\right]$ thymidine uptake in the following experiments.

Potentiation of $P D G F$-induced MC proliferation by $\mathrm{AP}_{5} \mathrm{~A}$ and $A P_{6} A$. Because PDGF is one of the most potent growth factors for $\mathrm{MC}$, we examined $\mathrm{AP}_{5} \mathrm{~A}$ and $\mathrm{AP}_{6} \mathrm{~A}$ for cooperative mitogenicity with PDGF. As depicted in Fig. 2 A, PDGF $B / B$ exerted a concentration-dependent mitogenic effect on MC between 1 and $50 \mathrm{ng} / \mathrm{ml}$. Together with $\mathrm{AP}_{5} \mathrm{~A}$ or $\mathrm{AP}_{6} \mathrm{~A}$ (both $10^{-5} \mathrm{M}$ ) an additive effect on $\mathrm{MC}$ growth was noted for $1 \mathrm{ng} /$ $\mathrm{ml}$ and $5 \mathrm{ng} / \mathrm{ml}$ PDGF. At $50 \mathrm{ng} / \mathrm{ml}$ PDGF, additional treatment of $\mathrm{MC}$ with $\mathrm{AP}_{5} \mathrm{~A}$ or $\mathrm{AP}_{6} \mathrm{~A}$ induced a potentiated proliferation

Table I. Mesangial Cell Growth after Stimulation by Diadenosine Pentaphosphate and Diadenosine Hexaphosphate $\left(A P_{5} A\right.$ and $\left.A P_{6} A\right)$ Counted by Light Microscopy

\begin{tabular}{|c|c|c|}
\hline & \multicolumn{2}{|c|}{$\begin{array}{l}\text { Mesangial cell counts } \\
\qquad\left(* 10^{4} / \mathrm{ml}\right)\end{array}$} \\
\hline Control & \multicolumn{2}{|c|}{$6.9 \pm 0.7$} \\
\hline Concentration (M) & $\mathrm{AP}_{5} \mathrm{~A}$ & $\mathrm{AP}_{6} \mathrm{~A}$ \\
\hline $10^{-7}$ & $7.2 \pm 0.8$ & $7.0 \pm 0.6$ \\
\hline $10^{-6}$ & $8.8 \pm 0.4 *$ & $8.9 \pm 0.7 *$ \\
\hline $10^{-5}$ & $11.1 \pm 1.0^{*}$ & $12.3 \pm 1.1^{*}$ \\
\hline $10^{-4}$ & $11.0 \pm 1.2 *$ & $12.5 \pm 1.2 *$ \\
\hline
\end{tabular}

Data are means \pm SD $(n=9) .{ }^{*} P<0.05$ compared with control.

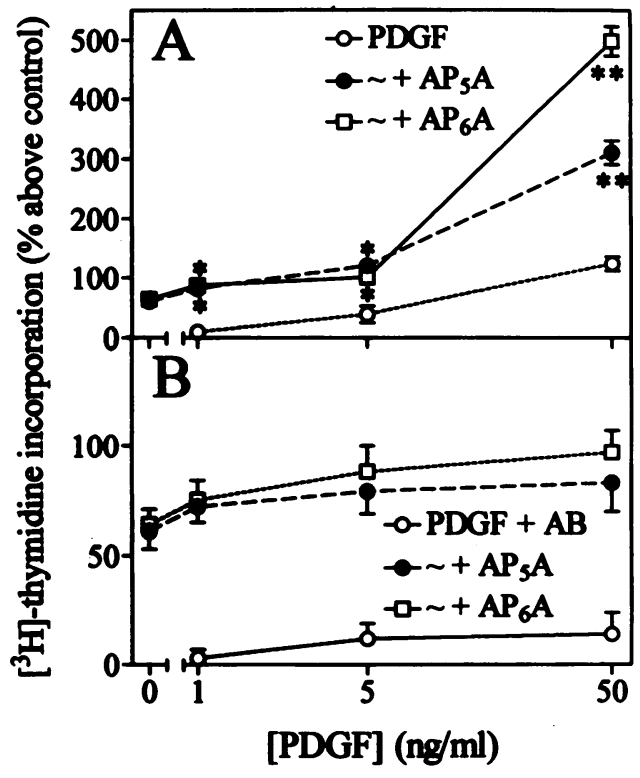

Figure 2. Effect of diadenosine phosphates and platelet-derived growth factor (PDGF) on $\left[{ }^{3} \mathrm{H}\right]$ thymidine incorporation (in \% above control) of mesangial cells. $(A)$ Effect of PDGF, PDGF plus $10^{-5} \mathrm{M}$ diadenosine pentaphosphate $\left(+A P_{5} A\right)$, and PDGF plus $10^{-5} \mathrm{M}$ diadenosine hexaphosphate $\left(+A P_{6} A\right)$. $(B)$ Effect of PDGF plus PDGF antibody (PDGF+AB), PDGF plus PDGF antibody plus $10^{-5} \mathrm{M}$ diadenosine pentaphosphate $\left(+A P_{5} A\right)$, and PDGF plus PDGF antibody plus $10^{-5}$ $M$ diadenosine hexaphosphate $\left(+A P_{6} A\right)$. Abscissa: PDGF concentration. Data are means \pm SD from four independent experiments with 10 cultures each. ${ }^{*} P<0.01 ;{ }^{*} P<0.001$, each compared with PDGF alone.

(PDGF alone $124 \pm 12 \%$ increase of proliferation above control; $\mathrm{AP}_{5} \mathrm{~A} 79 \pm 8 \%$ increase; $\mathrm{AP}_{6} \mathrm{~A} 85 \pm 10 \%$ increase; PDGF plus $\mathrm{AP}_{5} \mathrm{~A} 311 \pm 20 \%$ increase; $\mathrm{PDGF}$ plus $\mathrm{AP}_{6} \mathrm{~A} 498 \pm 25 \%$ increase, both $P<0.001$ compared with PDGF alone). When a PDGF antibody was added together with the diadenosine phosphates and PDGF, the synergistic effect was abolished, and only the growth stimulatory effect of the diadenosine phosphates remained (Fig. 2 B). The different action of PDGF and diadenosine phosphates was also reflected in the findings of cell cycle analysis performed after a $18 \mathrm{~h}$ culture (Fig. 3 ). In the presence

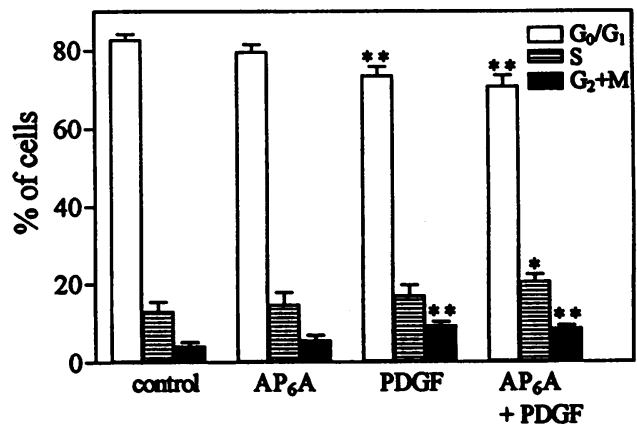

Figure 3. Determination of the cell cycle in mesangial cells, treated with medium (control), with $10^{-5} \mathrm{M}$ diadenosine hexaphosphate $\left(A P_{6} A\right), 50 \mathrm{ng} / \mathrm{ml}$ platelet-derived growth factor $(P D G F)$ and the combination of both $\left(A P_{6} A+P D G F\right)$ for $18 \mathrm{~h}$. Data are means \pm SD from five independent cultures. ${ }^{*} P<0.05$; ${ }^{* *} P<0.01$, compared with control. 


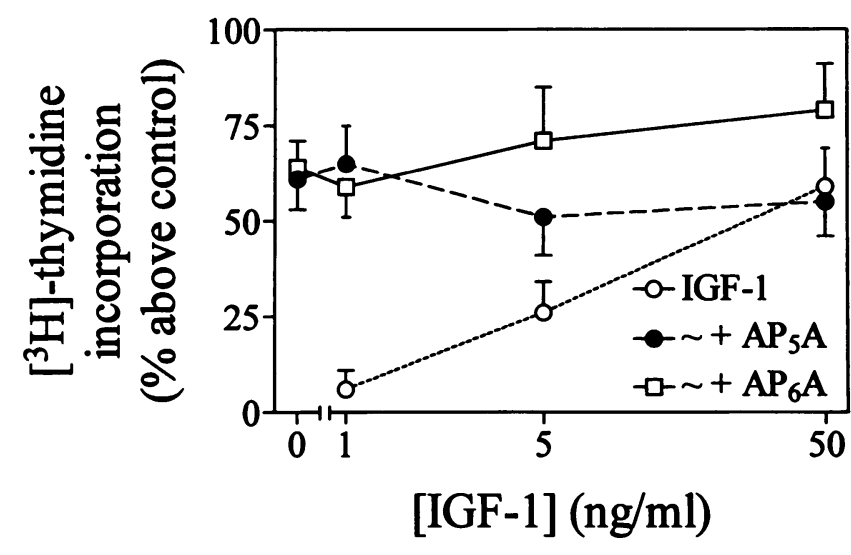

Figure 4. $\left[{ }^{3} \mathrm{H}\right]$ thymidine incorporation (in \% above control) of mesangial cells stimulated by insulin-like growth factor-1 (IGF-1), IGF-1 plus $10^{-5} \mathrm{M}$ diadenosine pentaphosphate $\left(+A P_{5} A\right)$, and IGF-1 plus $10^{-5} \mathrm{M}$ diadenosine hexaphosphate $\left(+A P_{6} A\right)$. Abscissa: IGF-1 concentration. Data are means $\pm S D$ from four independent experiments with 10 cultures each.

of $50 \mathrm{ng} / \mathrm{ml}$ PDGF, a progression to $G_{2}$ and $M$ phase was noted in the initially largely quiescent cells, whereas $\mathrm{AP}_{5} \mathrm{~A}$ (data not shown) or $\mathrm{AP}_{6} \mathrm{~A}$ (each $10^{-5} \mathrm{M}$ ) alone did not cause similar changes. By a simultaneous exposure of MC with PDGF and $\mathrm{AP}_{6} \mathrm{~A}$, progression to the $\mathrm{S}$ and $\mathrm{G}_{2} / \mathrm{M}$ phase was accelerated compared to PDGF treatment alone.

Effects of IGF-1 in combination with $A P_{5} A$ and $A P_{6} A$ on $M C$ growth. Since PDGF has been shown to act as a competence factor on the initial phase of the cell cycle of $\mathrm{MC}$, we also analysed the cooperation between $\mathrm{AP}_{5} \mathrm{~A}$ or $\mathrm{AP}_{6} \mathrm{~A}$ and the growth factor IGF-1. As shown in Fig. 4, IGF-1 alone exerted a concentration-dependent increase of $\mathrm{MC}\left[{ }^{3} \mathrm{H}\right]$ thymidine uptake between 1 and $50 \mathrm{ng} / \mathrm{ml}$. However, together with $\mathrm{AP}_{5} \mathrm{~A}$ or $\mathrm{AP}_{6} \mathrm{~A}$ (both $10^{-5} \mathrm{M}$ ) no additive or synergistic effects of IGF-1 on MC proliferation were observed, and the growth responses were similar to those with $\mathrm{AP}_{5} \mathrm{~A}$ or $\mathrm{AP}_{6} \mathrm{~A}$ alone.

$R N A$ and protein synthesis by $A P_{5} A$ and $A P_{6} A$. To further characterize the growth stimulatory effects of diadenosine phosphates, besides DNA also RNA and overall protein synthesis in response to $\mathrm{AP}_{6} \mathrm{~A}$ and $\mathrm{PDGF}$ were studied. As shown in Fig. $5 \mathrm{~A}, 10^{-5} \mathrm{M} \mathrm{AP}_{6} \mathrm{~A}$ had only minor effects on the overall RNA synthesis. Similar effects were also noted with $\mathrm{AP}_{5} \mathrm{~A}$ (data not shown). In contrast to RNA synthesis, the same concentrations of $\mathrm{AP}_{6} \mathrm{~A}$ induced a significant rise in overall protein synthesis of MC, which exceeded the effect of $50 \mathrm{ng} / \mathrm{ml}$ PDGF (Fig. $5 B$ ).

Effects of ATP, $\alpha, \beta$-methylene ATP, ATP $\gamma S$, and UTP in cooperation with $A P_{5} A$ or $A P_{6} A$ on $D N A$ synthesis by $M C$. As depicted in Fig. 6, ATP, the $\mathrm{P}_{2 \mathrm{x}}$ receptor agonist a, $\beta$-methylene ATP, the $\mathrm{P}_{2 \mathrm{y}}$ receptor agonist ATP g S and UTP, each in concentrations of $10^{-5} \mathrm{M}$, which were maximally effective, exerted a significant increase in DNA synthesis by MC compared with medium control. Compared to the four above mentioned agonists, $\mathrm{AP}_{5} \mathrm{~A}$ and $\mathrm{AP}_{6} \mathrm{~A}$ exerted a significantly elevated growth response of $\mathrm{MC}$ at concentrations of $10^{-5} \mathrm{M}(P<0.05)$. Simultaneous treatment with $\mathrm{AP}_{5} \mathrm{~A}$ or $\mathrm{AP}_{6} \mathrm{~A}$ and one of the above mentioned nucleotides did not further enhance the $\left[{ }^{3} \mathrm{H}\right]-$ thymidine uptake and only gave mitogenic responses similar to those of the diadenosine phosphates alone.

Measurements of cytosolic free $\mathrm{Ca}^{2+}$ concentration $\left(\left[\mathrm{Ca}^{2+}\right]_{i}\right)$.

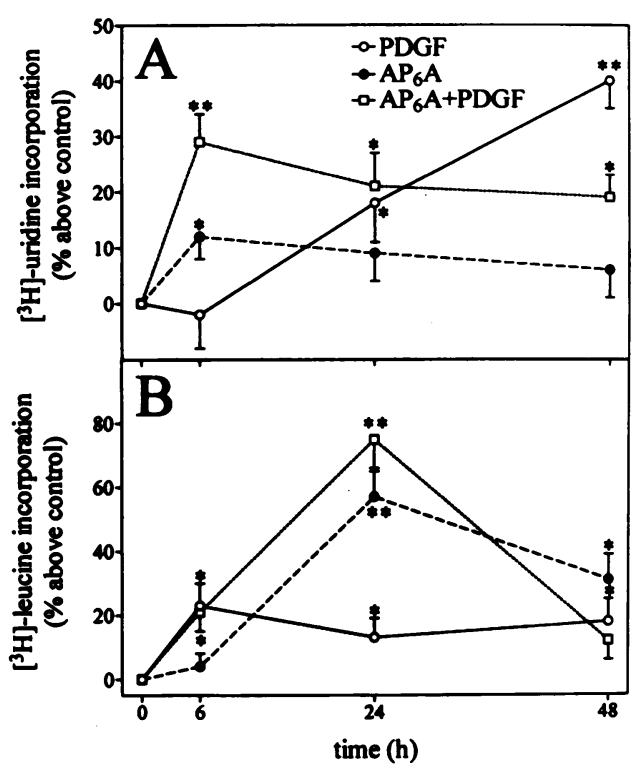

Figure 5. $\left[{ }^{3} \mathrm{H}\right]$ Uridine incorporation $(A)$ and $\left[{ }^{3} \mathrm{H}\right]$ leucine incorporation $(B)$ of mesangial cells stimulated by $10^{-5} \mathrm{M}$ diadenosine hexaphosphate $\left(A P_{6} A\right), 50 \mathrm{ng} / \mathrm{ml}$ platelet-derived growth factor $(P D G F)$, and PDGF plus $\mathrm{AP}_{6} \mathrm{~A}$ in the above mentioned concentrations over $48 \mathrm{~h}$. Data are means \pm SD from 12 cultures. $* P<0.05 ;{ }^{*} P<0.01$, each compared with control medium.

As shown in Fig. $7,10^{-5} \mathrm{M} \mathrm{AP} \mathrm{AP}_{6} \mathrm{~A}$ increased $\left[\mathrm{Ca}^{2+}\right]_{\mathrm{i}}$ by about $100 \mathrm{nM}$. Significant effects on $\left[\mathrm{Ca}^{2+}\right]_{\mathrm{i}}$ were also observed with $10^{-6} \mathrm{M}$. Compared with other agonists such as angiotensin II, $\mathrm{AP}_{6} \mathrm{~A}$ increased $\left[\mathrm{Ca}^{2+}\right]_{\mathrm{i}}$ less rapidly, but elicited a long-lasting $\left[\mathrm{Ca}^{2+}\right]_{\mathrm{i}}$ elevation, which persisted for $\sim 5 \mathrm{~min}$. $\mathrm{AP}_{5} \mathrm{~A}$ elicited similar effects as $\mathrm{AP}_{6} \mathrm{~A}$ (Fig. $7 \mathrm{~B}$ ). In $\mathrm{Ca}^{2+}$ free medium, $\mathrm{AP}_{5} \mathrm{~A}$ and $\mathrm{AP}_{6} \mathrm{~A}$ did not significantly affect $\left[\mathrm{Ca}^{2+}\right]_{\mathrm{i}}$ (data not shown).

\section{Discussion}

The results show that both $\mathrm{AP}_{5} \mathrm{~A}$ and $\mathrm{AP}_{6} \mathrm{~A}$ potently stimulate the growth of MC and potentiate the effect of PDGF. It is not

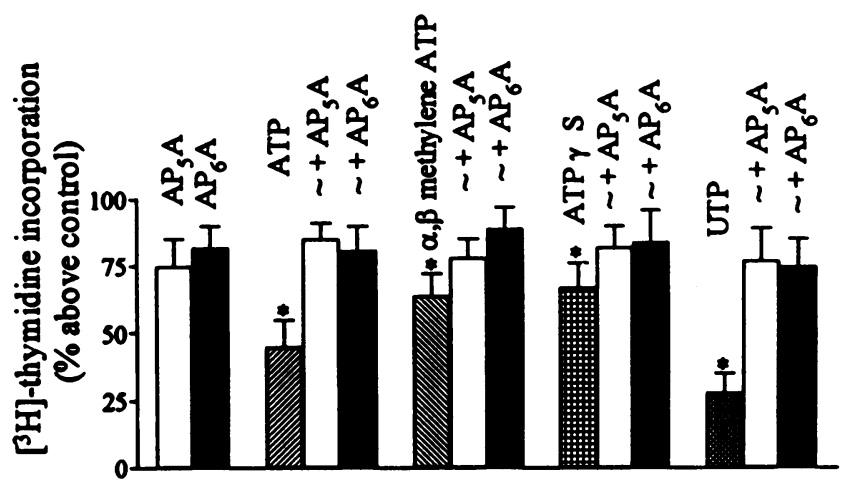

Figure 6. $\left[{ }^{3} \mathrm{H}\right]$ Thymidine incorporation of mesangial cells stimulated by $10^{-5} \mathrm{M}$ diadenosine pentaphosphate $\left(\mathrm{AP}_{5} \mathrm{~A}\right), 10^{-5} \mathrm{M}$ diadenosine hexaphosphate $\left(A P_{6} A\right), 10^{-5} \mathrm{M}$ adenosine triphosphate $(A T P), 10^{-5}$ $\mathrm{M} \alpha, \beta$-methylene ATP, $10^{-5} \mathrm{M}$ adenosine 5'-O-(3-thio)triphosphate (ATP $\mathrm{g} \mathrm{S}$ ) and $10^{-5} \mathrm{M}$ uridine triphosphate (UTP), each alone and together with $10^{-5} \mathrm{M} \mathrm{AP}_{5} \mathrm{~A}$ or $\mathrm{AP}_{6} \mathrm{~A}\left(\sim+A P_{5} A, \sim+A P_{6} A\right)$. Data are means \pm SD from three independent experiments with 10 cultures each. ${ }^{*} P<0.05$ compared with the effect of additional administration of $\mathrm{AP}_{5} \mathrm{~A}$ or $\mathrm{AP}_{6} \mathrm{~A}$ and of $\mathrm{AP}_{5} \mathrm{~A}$ or $\mathrm{AP}_{6} \mathrm{~A}$ alone. 

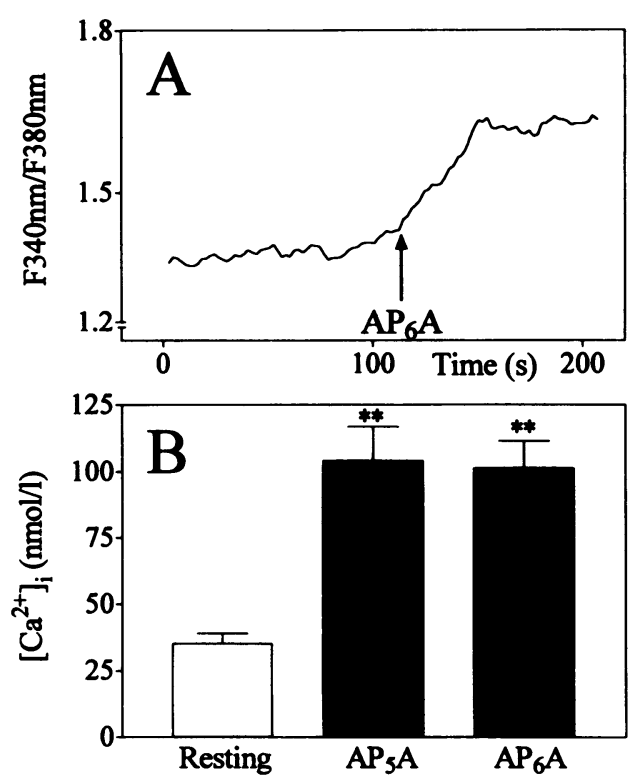

Figure 7. Effect of $10^{-5} \mathrm{M}$ diadenosine pentaphosphate $\left(A P_{5} A\right)$ or diadenosine hexaphosphate $\left(A P_{6} A\right)$ on cytosolic free $\mathrm{Ca}^{2+}$ concentration $\left(\left[\mathrm{Ca}^{2+}\right]_{\mathrm{i}}\right) .(A)$ Representative tracing out of 22 similar experiments showing the effect of $10^{-5} \mathrm{M} \mathrm{AP}{ }_{6} \mathrm{~A}$ on $\left[\mathrm{Ca}^{2+}\right]_{\mathrm{i}}$. Ordinate: ratio of fluorescence with $340 \mathrm{~nm}$ and $380 \mathrm{~nm}$ excitation (F340 nm/F380 nm). (B) Resting $\left[\mathrm{Ca}^{2+}\right]_{\mathrm{i}}$ and $\left[\mathrm{Ca}^{2+}\right]_{\mathrm{i}}$ induced by $\mathrm{AP}_{5} \mathrm{~A}$ or $\mathrm{AP}_{6} \mathrm{~A}$ (each $10^{-5}$ M). Data are means $\pm \mathrm{SD}(n=22$ each $) . * * P<0.0$ ! compared with resting $\left[\mathrm{Ca}^{2+}\right]_{\mathrm{i}}$.

clear which receptors are activated by the diadenosine phosphates. Apparently, similar effects on growth are elicited by both $\alpha, \beta$ methylene ATP and ATP $\gamma \mathrm{S}$, selective agonists of the $\mathrm{P}_{2 \mathrm{x}}$ and $\mathrm{P}_{2 \mathrm{y}}$ subtype of purinergic receptors (30). However, both agonists stimulated growth in a less degree compared with the diadenosine phosphates. This finding suggests that the diadenosine phosphates do not selectively activate either the $\mathrm{P}_{2 \mathrm{x}}$ or the $P_{2 y}$ receptor subtype. Furthermore, there are important differences between the growth stimulatory effects of diadenosine phosphates and ATP, which is known to stimulate growth in both MC and vascular smooth muscle cells (31-33). The maximal growth stimulatory effect of diadenosine phosphates exceeds that of ATP, suggesting that different receptors may be activated by diadenosine phosphates and ATP. Possibly, the selective diadenosine phosphate and ATP. Possibly, the selective diadenosine phosphate receptor described by Hilderman et al. in brain and myocardial tissue $(13,14)$ is the primary target of these agents.

$\mathrm{AP}_{5} \mathrm{~A}$ and $\mathrm{AP}_{6} \mathrm{~A}$ have been found in human platelets (6) and may also occur in other human tissues. Therefore the growth stimulatory effects of these substances could play a role in the development of glomerular damage in human disease such as glomerulonephritis or glomerulosclerosis. In addition to the action of polypeptide growth factors such as PDGF or basic fibroblast growth factor $(5,34)$, the diadenosine phosphates locally released by platelets could stimulate MC proliferation. Compared with ATP, the diadenosine phosphates are more potent growth factors, and from estimations of their concentrations in platelets, micromolar concentrations could be achieved by platelet aggregation (6). It has been shown that $\mathrm{AP}_{5} \mathrm{~A}$ and $\mathrm{AP}_{6} \mathrm{~A}$ are released nearly completely by thrombin-induced platelet aggregation (35).
Besides the growth stimulatory effect, both $\mathrm{AP}_{5} \mathrm{~A}$ and $\mathrm{AP}_{6} \mathrm{~A}$ potentiate the effect of PDGF, but not of IGF-1, on MC growth. Since PDGF may play a pivotal role in MC proliferation in response to glomerular damage, the synergistic effect of diadenosine phosphates may also be of importance. It may be speculated that the local concentration of diadenosine phosphates may modulate the effects of PDGF. Thus, the local diadenosine phosphate concentration could also indirectly determine mesangial cell proliferation in glomerular disease.

Interestingly, the effect of IGF-1 is not potentiated by $\mathrm{AP}_{5} \mathrm{~A}$ and $\mathrm{AP}_{6} \mathrm{~A}$. This suggests that diadenosine phosphates and IGF1 have the same site of action in the cell cycle as progression factors. It is known that IGF-1 stimulates the progression of late $G_{0} / G_{1}$ to the initiation of DNA synthesis, which requires protein synthesis, but not de novo RNA formation $(36,37)$. Similarly, diadenosine phosphates exerted much stronger effects on protein compared with RNA synthesis of MC. In contrast, the competence factor PDGF stimulated DNA synthesis in the initial phase of the cell cycle, before the diadenosine phosphates were active. The different mechanisms of growth stimulation may explain, why the action of PDGF, but not of IGF-1, can be potentiated by diadenosine phosphates.

The results furthermore show that diadenosine phosphates increase $\left[\mathrm{Ca}^{2+}\right]_{\mathrm{i}}$ in MC. In various cell types, it has been proposed that cellular $\mathrm{Ca}^{2+}$ handling and proliferation are closely linked (38). However, it is known that some growth factors stimulate growth without changing $\left[\mathrm{Ca}^{2+}\right]_{\mathrm{i}}(39)$. Therefore the changes in $\left[\mathrm{Ca}^{2+}\right]_{\mathrm{i}}$ induced by diadenosine phosphates may be more important in the regulation of $\mathrm{MC}$ contraction than of $\mathrm{MC}$ growth.

In summary, $\mathrm{AP}_{5} \mathrm{~A}$ and $\mathrm{AP}_{6} \mathrm{~A}$, newly recognized endogenous vasoconstrictive dinucleotides, may play a role in the regulation of MC growth under physiological and pathological conditions.

\section{Acknowledgments}

The study was supported by the Deutsche Forschungsgemeinschaft (grants He 1490/3-1, Zi 315/5-1).

\section{References}

1. Floege, J., E. Eng, B. A. Young, and R. J. Johnson. 1993. Factors involved in the regulation of mesangial cell proliferation in vitro and in vivo. Kidney Int. Suppl. 39:S47-S54.

2. Veis, J. H., W. Yamashita, Y. J. Liu, and B. S. Ooi. 1990. The biology of mesangial cells in glomerulonephritis. Proc. Soc. Exp. Biol. Med. 195:160-167.

3. Isaka, Y., Y. Fujiwara, N. Ueda, Y. Kaneda, T. Kamada, and E. Imai. 1993. Glomerulosclerosis induced by in vivo transfection of transforming growth factor$\beta$ or platelet-derived growth factor gene into the rat kidney. J. Clin. Invest. 92:2597-2601.

4. Shultz, P. J., P. E. DiCorleto, B. J. Silver, and H. E. Abboud. 1988. Mesangial cells express PDGF mRNAs and proliferate in response to PDGF. Am. J. Physiol. 255(4 Pt 2):F674-F684.

5. Sterzel, R. B., E. Schulze-Lohoff, and M. Marx. 1993. Cytokines and mesangial cells. Kidney Int. Suppl. 39:S26-S31.

6. Schlüter, H., E. Offers, G. Brüggemann, M. van der Giet, M. Tepel, E. Nordhoff, M. Karas, C. Spieker, H. Witzel, and W. Zidek. 1994. Diadenosine phosphates and the physiological control of blood pressure. Nature (Lond.). 367:186-188.

7. Garrison, P. N., and L. D. Barnes. 1992. Determination of dinucleoside polyphosphates. In AP4A and Other Dinucleoside Polyphosphates. A. McLennan, editor. CRC Press, Boca Raton. 29-61.

8. Busse, R., A. Ogilvie, and U. Pohl. 1988. Vasomotor activity of diadenosine triphosphate and diadenosine tetraphosphate in isolated arteries. Am. J. Physiol. 254:H828-H832.

9. Pohl, U., A. Ogilvie, D. Lamontagne, and R. Busse. 1991. Potent effects 
of AP3A and AP4A on coronary resistance and autacoid release of intact rabbit hearts. Am. J. Physiol. 260:H1692-H1697.

10. Weinmann-Dorsch, C., A. Hedl, I. Grummt, W. Albert, F. J. Ferdinand, R. R. Friis, G. Pierron, W. Moll, and F. Grummt. 1984. Drastic rise of intracellular adenosine $\left(5^{\prime}\right)$ tetraphospho $\left(5^{\prime}\right)$ adenosine correlates with onset of DNA synthesis in eukaryotic cells. Eur. J. Biochem. 138:179-185.

11. Yamaguchi, N., M. Kodama, and K. Ueda. 1985. Diadenosine tetraphosphate as a signal molecule linked with the functional state of rat liver. Gastroenterology. 89:723-731.

12. Baril, E. F., S. A. Coughlin, and P. C. Zamecnik. 1985. 5',5'"-P1,p4 diadenosine tetraphosphate (ap4a): a putative initiator of DNA replication. Cancer Invest. 3:465-471.

13. Hilderman, R. H., M. Martin, J. K. Zimmerman, and E. B. Pivorun. 1991. Identification of a unique membrane receptor for adenosine $5^{\prime}, 5^{\prime \prime}$ '-P1,P4tetraphosphate. J. Biol. Chem. 266:6915-6918.

14. Walker, J., T. E. Lewis, E. P. Pivorun, and R. H. Hilderman. 1993. Activation of the mouse heart adenosine 5',5"'-P1-P4 tetraphosphate receptor. Biochemistry. 32:1264-1269.

15. Hoyle, C. H. V., C. Chapple, and G. Burnstock. 1989. Isolated human bladder: evidence for an adenine dinucleotide acting on $\mathrm{P} 2 \mathrm{x}$-purinoceptors and for purinergic transmission. Eur. J. Pharmacol. 174:115-118.

16. MacKenzie, I., K. A. Kirkpatrick, and G. Burnstock. 1988. Comparative study of the actions of AP5A and alpha,beta methylene ATP on nonadrenergic, noncholinergic neurogenic excitation in the guinea-pig vas deferens. $\mathrm{Br}$. J. Pharmacol. 94:699-706.

17. Wolthuis, A., A. Boes, H. P. Rodemann, and J. Grond. 1992. Vasoactive agents affect growth and protein synthesis of cultured rat mesangial cells. Kidney Int. 41:124-131.

18. Jaffer, F. E., T. C. Knauss, E. Poptic, and H. E. Aboud. 1990. Endothelin stimulates PDGF secretion in cultured human mesangial cells. Kidney Int. 38:1193-1198.

19. Haneda, M., R. Kikkawa, D. Koya, T. Uzu, S. Maeda, M. Togawa, and Y. Shigeta. 1993. Alteration of mesangial response to ANP and angiotensin II by glucose. Kidney Int. 44:518-526.

20. Harper, P. A., R. M. Robinson, R. L. Hoover, T. C. Wright, and M. J. Karnovsky. 1984. Improved methods for culturing rat glomerular cells. Kidney Int. 26:875-880.

21. Striker, G. E., and L. J. Striker. 1985. Biology of disease: Glomerular cell culture. Lab. Invest. 53:122-131.

22. Osanai, T., and M. J. Dunn. 1992. Phospholipase C responses in cells from spontaneously hypertensive rats. Hypertension. 19:446-455.

23. Silver, B. J., F. E. Jaffer, and H. E. Abboud. 1989. Platelet-derived growth factor synthesis in mesangial cells: induction by multiple peptide mitogens. Proc. Natl. Acad. Sci. USA. 86:1056-1060.

24. Ganz, M. B., S. K. Pekar, M. C. Perfetto, and R. B. Sterzel. 1988. Arginine vasopressin promotes growth of rat glomerular mesangial cells in culture. Am. J. Physiol. 255:F898-F906.
25. Heidenreich, S., J. H. Gong, A. Schmidt, M. Nain, and D. Gemsa. 1989. Macrophage activation by granulocyte/macrophage colony-stimulating factor. Priming for enhanced release of tumor necrosis factor-A and prostaglandin E2. J. Immunol. 143:1198-1205.

26. Simonson, M. S., and M. J. Dunn. 1991. Ca2+ signaling by distinct endothelin peptides in glomerular mesangial cells. Exp. Cell Res. 192:148-156.

27. Bonventre, J. V., P. C. Weber, and J. H. Gronich. 1988. PAF and PDGF increase cytosolic [ $\mathrm{Ca} 2+]$ and phospholipase activity in mesangial cells. Am. J. Physiol. 254(1 Pt 2):F87-F94.

28. Grynkiewicz, G., M. Poenie, and R. Y. Tsien. 1985. A new generation of $\mathrm{Ca} 2+$ indicators with greatly improved fluorescence properties. J. Biol. Chem. 260:3440-3450.

29. Nordhoff, E., A. Ingendoh, R. Cramer, A. Overberg, B. Stahl, M. Karas, and F. Hillenkamp. 1992. Matrix-assisted laser desorption/ionization mass spectrometry of nucleic acids with wavelengths in the ultraviolet and infrared. Rapid Comm. Mass Spectrom. 6:771-776.

30. Burnstock, G. 1991. Distribution and roles of purinoceptor subtypes. $\mathrm{Nu}$ cleosides and Nucleotides. 10:917-930.

31. Schulze-Lohoff, E., S. Zanner, A. Ogilvie, and R. B. Sterzel. 1992. Extracellular ATP stimulates proliferation of cultured mesangial cells via P2-purinergic receptors. Am. J. Physiol. 263:F374-F383.

32. Malam-Souley, R., M. Campan, A.-P. Gadeau, and C. Desgranges. 1993. Exogenous ATP induces a limited cell cycle progression of arterial smooth muscle cells. Am. J. Physiol. 264:C783-C788.

33. Erlinge, D., H. Yoo, L. Edvinsson, D. J. Reis, and C. Wahlestedt. 1993. Mitogenic effects of ATP on vascular smooth muscle cells vs. other growth factors and sympathetic cotransmitters. Am. J. Physiol. 265:H1089-H1097.

34. Floege, J., E. Eng, B. A. Young, C. E. Alpers, T. B. Barrett, D. F. BowenPope, and R. J. Johnson. 1993. Infusion of platelet-derived growth factor or basic fibroblast growth factor induces selective glomerular mesangial cell proliferation and matrix accumulation in rats. J. Clin. Invest. 92:2952-2962.

35. Agha, A., H. Schlüter, S. König, K. Biel, M. Tepel, and W. Zidek. 1992. A novel platelet-derived renal vasoconstrictor agent in normotensives and essential hypertensives. J. Vasc. Res. 29:281-289.

36. Olashaw, N. E., J. J. van Wyk, and W. J. Pledger. 1987. Control of late G0/G1 progression and protein modification by SmC/IGF I. Am. J. Physiol. 253:C575-C579.

37. Doi, T., L. J. Striker, S. J. Elliot, F. G. Conti, and G. E. Striker. 1989. Insulinlike growth factor-1 is a progression factor for human mesangial cells. Am. J. Pathol. 134:395-404.

38. Hazelton, B., B. Mitchell, and J. Tupper. 1979. Calcium, magnesium and growth control in the WI-38 human fibroblast cell. J. Cell Biol. 83:487-498.

39. Heidenreich, S., M. Tepel, D. Lang, K. H. Rahn, and W. Zidek. 1994 Differential effects of insulin-like growth factor I and platelet-derived growth factor on growth response, matrix formation, and cytosolic free calcium of glomerular mesangial cells of spontaneously hypertensive and normotensive rats. Nephron. $68: 481-488$. 